\title{
The Effect of Feeding Calcium Soap of Fatty Acids and Sodium Acetate on the Physiological Responses of Dairy Cows
}

\author{
Takamitsu Air, Mitsunori Kurihara, Shinichi Kume, \\ Mamoru Tomita ${ }^{*}$ and Hirotoshi Hayasawa* \\ Kyushu National Agricultural Experiment Station, \\ Nishigoshi-cho, Kumamoto-ken 861-11 \\ * Nutritional Science Laboratory, Morinaga Milk \\ Industry Co., Ltd. Zama-shi 228
}

(Received February 19, 1990)

Key words : calcium soap, acetate, dairy cows, milk yield, milk fat content

Vegetable and animal oils and acetates are well known as precursors of milk fat in the body of cows.

Recently, some commercial calcium soaps of fatty acids have been prevalent as a supplement feed to dairy cows in Japan in order to elevate the milk fat content. However, they are generally not palatable to dairy cows and therefore an improvement of their taste is required.

On the other hand, vinegar has long been fed to animals by some dairy farmers in Japan for the above purpose. This paper deals with the milk yield, milk fat content, number of rumen protozoa, values of blood metabolites, etc. of the cows given calcium soap of fatty acids and sodium acetate. Sodium acetate was selected as a source of acetic acid for convenience in handling.

\section{Materials and Methods}

Calcium soap :
The production of calcium soap was carried out by Taiyo Yushi Co., Ltd. (Yokohama).

In brief, the procedure for the preparation of calcium soap is as follows; $100 \mathrm{~g}$ of commercial soybean oil, whose fatty acids consisted of linoleic $(50 \%)$, oleic $(23 \%)$, palmitic $(10 \%)$, linolenic $(7 \%)$ and other acids, was added 13.6 $\mathrm{g}$ of calcium hydroxide and $150 \mathrm{~g}$ of water and stirred. Fifty $\mathrm{mg}$ of $0.5 \%$ lipase derived from Psudomonas Fluorescens (Amano Pharmaceutical Co., Ltd.) was added to the mixture and stirred to gel. After standing for 3-5 hrs, the gel separated into liquid and solid. The calcium soap obtained from the solids was airdried at room temperature for 7-8 hrs and crashed.

The energy value and calcium content of calcium soap were $7,750 \mathrm{cal} / \mathrm{g}$ and $6.3 \%$, respectively.

Sodium acetate :

Anhydrous sodium acetate of a feed additive was purchased from the Nippon Synthetic

脂肪酸カルシゥムと酢酸ナトリウムの給与が乳牛の生理機能に与える影響: 相井孝允・栗原光規・久光新一・冨田 守*・早澤宏紀*（農林水産省九州農業試験場 熊本県西合志町 861-11 * 森永乳業食品総合研究所 座間市 228 ) 
Chemical Industry Co., Ltd. (Osaka).

Animals :

Six Holstein cows with an average of $19.9 \mathrm{~kg}$ milk yield, weighing an average of $610 \mathrm{~kg}$, were used in Expts 1-1 1-3.

Ration :

The cows received corn haylage ad lib., in addition to a formula feed [barley $(40 \%)+$ maize $(11 \%)+$ defatted rice bran $(10 \%)+$ wheat bran $(10 \%)+$ linseed oil meal $(20 \%)+$ soybean meal $(5 \%)+$ salt $(1.5 \%)+$ calcium carbonate $(2.5 \%)]$ and beet pulp heing equivalent to the nutrient requirements for milk yield according to the Japan Feeding Standard for Dairy Cattle (1978): The cows were given a formula feed and beet pulp during the morning and evening milking times ( $8: 30$ and $16: 30 \mathrm{~h}$ ) and received corn haylage ad lib. at the paddock except during milking times. However, for the last 5 days of every period in Expts 1-2 and $1-3$, the cows were kept in the stanchion barn from $8: 30$ to $20: 00 \mathrm{~h}$ and the feed intake with roughage was determined.

Feeding procedure :

Six lactating Holstein cows were separated into 3 groups with 2 cows each (Expt 1-1, Expt 1-2 and Expt 1-3). These three cow groups were offered the ration only for the first 2 weeks (1st period), and for the next 2 weeks (2nd period) they were given $420 \mathrm{~g} / \mathrm{head} /$ day of calcium soap of fatty acids in Expt 1-1, 420 $\mathrm{g} / \mathrm{head} /$ day of sodium acetate in Expt 1-2 and $210 \mathrm{~g} / \mathrm{head} /$ day of the calcium soap and 210 $\mathrm{g} /$ head/day of the sodium acetate in Expt 1-3, respectively, in addition to the same ration during the 1st period. Subsequently, the cows returned to the ration only for the last 2 weeks ( $3 \mathrm{rd}$ period). The individual supplements were completely mixed with a formula feed before feeding. The quantity ratio of the supplement feeding in the morning to that of the evening was $3: 2$.

Sampling of milk, blood and rumen juice :

Milk samples were collected during the last 5 days of every period. Morning and evening milk were combined, and analyzed for milk fat, protein and total milk solid. A part of the milk samples were frozen at $-20^{\circ} \mathrm{C}$ until the determination of milk fatty acids composition. Milk yield was recorded daily. Blood and rumen juice were taken from the jugular vein and from rumen through a rumen catheter, respectively, at $13: 00$ to $14: 00 \mathrm{~h}$ on the 9 th and 11th day every period except in Expt 1-1.

Analytical methods :

Milk fat, protein and total milk solid were determined with a Gerber method, a Kjeldahl method and by a TMS Checker (K 375 A, Anritsu Electric Inc., Ltd.). Milk fatty acid composition was analyzed according to our procedure $^{1)}$. Fatty acid productions (FAP) were calculated as follows :

FAP $(\mathrm{g})=$ milk fat production $(\mathrm{g}) \times$ each fatty acids group $\%$ in the chromatogram $x$ 0.98 (glyceride \% in butter fat) $\times 0.945$ (a factor obtained from the saponification value of butter fat)

The determination of volatile fatty acids and the count of protozoa number were performed with SUDo's method ${ }^{9)}$ and KurIHARA and TAKECHI's method ${ }^{5)}$, respectively. The biological analyses for blood serum, total lipids, total cholesterol, triglyceride. HDL-cholesterol and NEFA were performed using an auto-analyzer (ACL 6000, Olympus Optical Co., Ltd.) via the CHEEK and WeAse's method ${ }^{2)}$, the COD-POD$4 \mathrm{AA}$ method $^{3)}$ and the Gly-OD-POD method ${ }^{10)}$, using a spectrophotometer (UVIDEC-60, Japan Spectroscopic Co., Ltd.) via the phosphotungstic acid- $\mathrm{Mg}$ method ${ }^{7)}$ using an auto-analyzer (Centri-Phychem 400, Union Carbide Co., Ltd.) via the ATP-POD-4 AA method ${ }^{6)}$, respectively. The analyses were carried out at a chemical analysis laboratory (Higo Rinsho Kensa Kenkyusho Co., Ltd.).

\section{Results and Discussion}

As shown in Table 1, the C 18 group (stearic, oleic, linoleic and linolenic adids) in the milk fatty acids remarkably increased from 37.10 to 
Feeding of Calcium Soap and Acetate

Table 1. Physiological responses of the dairy cows when taken calcium soap and sodium acetate

\begin{tabular}{|c|c|c|c|c|c|c|}
\hline & \multicolumn{2}{|c|}{ Expt 1-1 } & \multicolumn{2}{|c|}{ Expt 1-2 } & \multicolumn{2}{|c|}{ Expt $1-3$} \\
\hline & Supplement ${ }^{17}$ & Cont. & Supplement ${ }^{2 \prime}$ & Cont. & Supplement ${ }^{3 \prime}$ & Cont. \\
\hline Milk yield (kg/day) & 12.6 & 17.4 & 22.1 & 21.1 & 20.9 & 20.4 \\
\hline Milk fat yield (g/day) & 531 & 579 & 838 & 798 & 733 & 669 \\
\hline \multicolumn{7}{|l|}{ Milk composition ( $\$ 6)$} \\
\hline Fat & 3.19 & 3.34 & 3.79 & 3.78 & 3.51 & 3. 27 \\
\hline Protein & 3.11 & 3.08 & 2.96 & 2.99 & 2.99 & 3.01 \\
\hline Total solids & 11.78 & 12.19 & 12.38 & 12.33 & 12.21 & 11.94 \\
\hline \multicolumn{7}{|c|}{ Milk fatty acid composition( $\mathscr{6})$} \\
\hline C4 $\sim$ C14 group & 23.23 & 27.18 & 29.04 & 30.05 & 26.56 & 29.42 \\
\hline C16 group & 29.59 & 35.72 & 41.73 & 38.61 & 38.39 & 45.67 \\
\hline C18 group & 47.19 & 37.10 & 29.24 & 31.34 & 35.04 & 24.92 \\
\hline \multicolumn{7}{|c|}{ Milk fatty acids production (g/day) } \\
\hline $\mathrm{C} 4 \sim \mathrm{C} 14$ group & 118 & 138 & 212 & 204 & 172 & 177 \\
\hline C16 group & 155 & 180 & 304 & 268 & 247 & 238 \\
\hline C18 group & 185 & 189 & 213 & 218 & 225 & 173 \\
\hline Rumen pH & & & 7.2 & 6.9 & 7.1 & 3.0 \\
\hline \multicolumn{7}{|l|}{ Rumen VFA (96) } \\
\hline Ac/Total VFA & & & 60.9 & 58.8 & 59.3 & 57.9 \\
\hline Pr/Total VFA & & & 18.5 & 19.9 & 19.6 & 19.8 \\
\hline But/Total VFA & & & 15.8 & 16.4 & 15.3 & 16.0 \\
\hline $\mathrm{Ac} / \mathrm{Pr}$ & & & 3.3 & 3.0 & 3.1 & 3.0 \\
\hline Rumen protozoa $\left(\times 10^{4} / \mathrm{ml}\right)$ & & & 41.7 & 44.0 & 40.6 & 38.3 \\
\hline \multicolumn{7}{|l|}{$\begin{array}{l}\text { Metabolite concentrations } \\
\text { in bloud serum (mg/d } l \text { ) }\end{array}$} \\
\hline Total lipids & 343 & 360 & 492 & 469 & 420 & 389 \\
\hline Trigly ceride & 9 & 8 & 8 & 8 & 11 & 8 \\
\hline NEFA & 386 & 402 & 453 & 454 & 415 & 405 \\
\hline Total cholesterol & 115 & 148 & 215 & 204 & 141 & 132 \\
\hline HDL-cholesterol & 68 & 72 & 80 & 79 & 67 & 67 \\
\hline Feed intake $(\mathrm{DM} \mathrm{kg})^{51}$ & & & 7.2 & 8.0 & 7.8 & 7.8 \\
\hline Body weight $(\mathrm{kg})$ & \multicolumn{2}{|l|}{$\cdots 514 \cdots$} & 630 & 621 & 691 & 692 \\
\hline
\end{tabular}

Note : 1;Calcium soap supplement. 2; Sodium acetate supplement. 3; Calcium soap and sodium acetate supplement. 4; Non-esterified fatty acids $(\mathrm{Eq} / l)$. 5; Feed intake of roughage for 8:30 20:00 h. Ac; acetic acid, Pr; propionic acid, But; butyric acid.

Cont. indicates an average of the values obtained in Expts 1st and 3rd period.

$47.19 \%$ when $420 \mathrm{~g} / \mathrm{head} /$ day of calcium soap was given to the dairy cows, whereas the $\mathrm{C} 4-\mathrm{C}$ 14 group (the acids from butyric acid to myristic acid, including decenoic and tetradecenoic acids) and the C 16 group (palmitic and palmitoleic acids) decreased from 27.18 to $23.23 \%$ and from 35.72 to $29.59 \%$, respectively. Milk fat content and its production decreased by $0.15 \%$ and by $48 \mathrm{~g} /$ day, respectively. From these results, it is assumed that the feeding of $420 \mathrm{~g} / \mathrm{head} / \mathrm{day}$ of calcium soap, which was performed on the feeding of a formula feed with about $5 \%$ calcium soap, inhibits the de novo synthesis of the $\mathrm{C} 4-\mathrm{C} 14$ and $\mathrm{C} 16$ groups in the animal body. STORRY et al. ${ }^{8)}$ demonstrated the yield reduction in $\mathrm{C} 4-\mathrm{C} 14$ and $\mathrm{C} 16$ groups on the feeding of a formula feed with more than $4 \%$ tallow to dairy cows. This reduction is probably due to a feedback inhibition on acetyl-CoA carboxylase by the increased concentrations of long chain acyl-CoA in the mammary gland. Therefore, the report indicates that the feeding of a formula feed with less than $4 \%$ oil supplement may not inhibit the de novo synthesis of the short- and intermediate-chain fatty acids in the gland. 


\section{Ait, Kurihara, Kume, Tomita and Hayasawa}

When $420 \mathrm{~g} / \mathrm{head} / \mathrm{day}$ of sodium acetate was given, the $\mathrm{C} 16$ group increased from 38.61 to $41.73 \%$, but the $\mathrm{C} 4-\mathrm{C} 14$ and $\mathrm{C} 18$ groups slightly decreased. Accordind to KNIGHT et $a l .{ }^{4)}$, when $\left[1{ }^{14} \mathrm{C}\right]$ acetate was infused intraruminally into a sheep, the labeled acetate was incorporated mainly into the microbial palmitate in the rumen. In the case of our experiment, it is assumed that most of the sodium acetate ingested was incorporated into the microbial palmitate, and the palmitate was transformed into milk fat in the mamnary glands to increase the proportion of palmitic acid in the milk fatty acids. Milk yield and milk fat production tended to increase when sodium acetate was given, but milk fat content scarcely changed. An acetic/propionic acid ratio in the rumen juice tended to broaden because of the ingestion of sodium acetate.

When the supplement composed of $210 \mathrm{~g}$ of calcium soap and $210 \mathrm{~g}$ of sodium acetate was given, the $\mathrm{C} 18$ group markedly increased from 24.92 to $35.04 \%$, whereas the C $4-\mathrm{C} 14$ and C 16 groups decreased remarkably. Milk yield, milk fat content and the fat production increased by $0.5 \mathrm{~kg}$, by $0.24 \%$ and by $64 \mathrm{~g} /$ day, respectively. Although the productions of $\mathrm{C} 4-\mathrm{C} 14$ and C 16 groups during the 2 nd period was slightly different from those during the 1st and 3rd periods, the C 18 group showed a markedly increased production. These facts indicate that feeding the proper quantities of calcium soap and sodium acetate elevates not only milk fat content but also milk yield and milk fat production, and that a considerable amount of the calcium soap of fatty acids is incorporated into the long chain fatty acids of milk fat.

In the later experiments done by the authors, daily milk yield and milk fat production increased by $0.3-0.4 \mathrm{~kg}$ and $62-91 \mathrm{~g}$, respectively, when $220 \mathrm{~g}$ of calcium soap and $280 \mathrm{~g}$ of sodium acetate was given to the dairy cows.

The number of protozoa in the rumen juice and the metabolite concentrations in the blood serum were recognized not to be influenced by the feeding of sodium acetate and calcium soap.

\section{Acknowledgements}

We are grateful to Dr. H. TANAKa (National Institute of Animal Industry) for his helpful suggestions and observations and his critical reading of the manuscript. The authors also would like to thank Taiyo Yushi Co., Ltd. for providing calcium soap of soybean oil.

\section{References}

1) Ail, T., S. Takahashi, M. Kurihara and S. Kume, Fatty acid composition of milk during a hot summer. Jpn. J, Zootech. Sci., 59 : 278-284. 1988.

2) CHEEK, S.C. and D.F. WEASE, A summation technic for serum total lipids. Comparison of methods. Clinical Chemistry, $15:$ 102-107. 1969.

3) KanAI, I., Rinsho Kensaho Teiyo. 29th ed. 456-457. Kanehara Shuppan. Tokyo. 1983.

4) KNight, R., J.D. SutTon, J.E. StoRRY and P.E. BRUMBY, Rumen microbial synthesis of long-chain fatty acids. Proc. Nutr. Soc. $38: 4$ A. 1978.

5) Kurihara, K. and T. Takechi, in Usi no Rinsho Kensaho. 1st ed. (Nakamura, T., T. Yonemura and K. Sudo, eds.) 6.14-6.17. Nosan Gyoson Bunka Kyokai. Tokyo. 1973.

6) Maenata,A., Free Fatty Acids. Medical Technology, 8 : 1029-1042. Ishiyaku Publishers, Inc. Tokyo. 1980.

7) NomA, A., HDL-cholesterol (A precipitation method). Medical Technology, 8 : 1092-1096. Ishiybku Publishers, Inc. Tokyo. 1980.

8) StORry, J.E., A.J. HALL and V.W. Johnson, The effects of increasing amounts of dietary tallow on milk-fat secretion in the cow. J. Dairy Res., 40 : 293299. 1973.

9) Sudo, K., in Usi no Rinsho Kensaho. 1st ed. (NAKamura, R., T. Yonemura and K. Sudo, eds.) 6.39-6.42. Nosan Gyoson Bunka Kyokai. Tokyo. 1973.

10) UEDA, H., Triglycerides (A enzymic method). Medical Technology, 8: 1014-1019. Ishiyaku Publishers, Inc. Tokyo. 1980. 